\title{
A review of available hybrid renewable energy systems in Malaysia
}

\author{
Nur Huda. M Binti Tambi ${ }^{1}$, Hadi Nabipour Afrouzi ${ }^{2}$, Kamyar Mehranzamir $^{3}$, Jubaer Ahmed ${ }^{4}$ \\ ${ }^{1,2,4}$ Faculty of Engineering, Computing and Science, Swinburne University of Technology Sarawak, Malaysia \\ ${ }^{3}$ Department of Electrical and Electronic Engineering, Faculty of Science and Engineering, \\ University of Nottingham Malaysia, Malaysia
}

\begin{tabular}{l}
\hline \hline Article Info \\
\hline Article history: \\
Received Jul 27, 2019 \\
Revised Oct 28, 2019 \\
Accepted Nov 29, 2019 \\
\hline
\end{tabular}

Keywords:

Biomass

Hybrid system

Renewable energy

Solar energy

Wind energy

\begin{abstract}
The utilization of conventional sources of energy releases harmful pollutants to the environment causing global warming and acid rain. For that reason, it becomes necessary to use a non-depletable, sustainable and eco-friendly renewable energy as a mean of producing electricity. Malaysia is tropical country rich in resources beneficial in electricity generation as it is in equatorial region therefore it has an abundance of solar irradiance of average annually. In addition, Malaysia's demand in electricity is increasing to $124,677 \mathrm{GWh}$ by 2020 . Therefore, the electricity generation from renewable sources in Malaysia is anticipated to grow in the future alongside the government endorsement due to its clean, eco-friendly and free source of energy which can highly reduce the dependency on oil and gas that emits harmful pollutants to the environment. This paper gives a comprehensive review on the renewable projects and researches in Malaysia, challenges that affect popularity of renewable energy in Malaysia and available and successful renewable energy system in Malaysia.
\end{abstract}

This is an open access article under the CC BY-SA license.

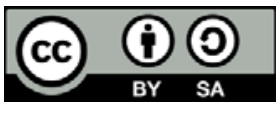

\section{Corresponding Author:}

Hadi Nabipour Afrouzi,

Faculty of Engineering, Computing and Science,

Swinburne University of Technology Sarawak,

93350 Kuching, Malaysia

Email: HAfrouzi@swinburne.edu.my

\section{INTRODUCTION}

The rapid population growth leads to the huge increment in world energy consumption, which gives rise to environmental issues such as pollutions, greenhouse emissions, and climate change. These environmental problems brought by the large energy consumption are becoming more apparent especially in newly industrialized and developing countries such as China and Malaysia where the energy usage is growing rapidly or used less efficiently, and the environmental impact management are not fully incorporated into the country's industrial activities. The solution to this will be the implementation of renewable energy sources that could greatly bring a positive change to the environment.

There are however, worries and question on whether they would affect the economy of a country positively or negatively. Will a shift from the fossil fuel generated power to the Renewable Energy (RE) sector change the way the world is going to function economically? This is because in terms of the environment, it would bring positive outcome that is very much needed to bring a stop to the climate change the world is facing today. It would be impossible and out of scope to cover the whole world due to time and pages limitation. Instead, the scope of this investigation will be based in Malaysia. This research investigates on the previous research, available and successful renewable energy system such as solar energy, wind 
energy and biomass in Malaysia. This review can have a significant contribution to the future development of renewable energy system in the country.

\section{RENEWABLE ENERGY IN MALAYSIA}

\subsection{Solar energy}

Solar energy is derived from the conversion of solar radiation into electrical energy with the use of photovoltaic panels. Sampaio and Gonzalez illustrated the essential components of photovoltaic, which are the semiconductors created from two energy bands [1]. Solar energy plays the role of the most dominant renewable energy source, as the amount of incident solar radiation on earth in 1 hour is more than the total consumed energy by humans for the entire year. Technologies to utilize solar energy have gain many interests in recent year due to high depletion rate of fossil fuel and increased population all over the world. The International Energy Agency predicts that solar energy system will become one of the main suppliers of household electricity, contributing to at least $17 \%$ of the global electricity demand by the year 2050 .

Most photovoltaic technology available in the market uses silicon cells, which can be in the form of monocrystalline and polycrystalline. Another technology in the photovoltaic manufacturing industry uses thin film elements comprises of copper, copper indium selenide (CIS), indium and gallium-diselenide (CIGS), amorphous silicon cells (a-Si) and Cadmium telluride (CdTe) [1, 2]. All these types of solar panel are available at Malaysia market. Furthermore, Malaysia is one of the largest solar panel producers in the world [3].

Solar energy as a source of electricity has been implemented in various countries around the world. Solar electricity has powered $4.6 \%$ of total generation in Germany, which equals to $32,000 \mathrm{MW}$ capacity. Meanwhile, Mexico received $0.15 \%$ of its total electricity from solar resource, which provides $52 \mathrm{MW}$ of the system capacity [4]. The amount of solar irradiation that Malaysia receive per day is significant and it is around $17 \mathrm{MJ}$ per sq. $\mathrm{m}$ in average [5, 6]. However, In Malaysia, photovoltaic technology contributes to 9 MW of electric capacity annually by 2011 [7]

Moreover, numerous researches have been done by many researchers around the world on photovoltaic technology. Pan et al. conducted a study on the effectiveness of a portable solar photovoltaic to provide electricity for a vehicle cabin using wireless power transfer method [8]. Khare et al. analysed the functionality of solar renewable in India [9]. Bakhtyar et al. performed a review on the Malaysian policy of feed-in tariff for solar electricity market [7]. Wong et al. examined a study on the grid-connected photovoltaic concept by focusing on voltage issues [10]. Rahman et al. evaluated the effects of operational conditions like ambient temperature, irradiation intensity, humidity and dust on the energy competency of photovoltaic technology in Malaysia [11, 12]. Parida et al. conducted a review on photovoltaic technology, its capacity producing ability, the varying existing performance and reliability assessment models, sizings and grid distribution and connection [12]. Kaa et al. used crisp and fuzzy technique to analyse the data to determine the most dominant design of five photovoltaic technologies that are currently available in the market [13]. Brabec discussed the techno-economical analysis of organic photovoltaics innovation, while Garcia-Valverde et al. and Wender et al. performed the life cycle evaluation of this technology [14, 15]. Fisac et al. studied the photovoltaic development model with thermoelectric by integrating temperature gradient to its structure for power production [15]. Sampaio et al. determined the photovoltaic cells technological development by analysing patents and obtained a set of patent types which have high precedence in technology $[16,17]$. Sinke examined the improvement of photovoltaic advancements and their impact to global sustainable energy system [17]. Husain et al. reviewed transparent solar panels technologies and Mitzi et al. evaluated the prospect and efficiency constraint of photovoltaic technologies [18, 19]. Shah et al., Meillaud et al. and Giraldo et al. performed a study on the perspectives, operation principles and physical performance constraint for the case of thin-film photovoltaic cells [20-22]. Jeon et. al. proposed a technique to estimate optimum financial subsidy and research and development investment for photovoltaic advancements by using system dynamics [22]. Zhou and Carbajales-Dale assessed performance and energy return on investment (EROI) for photovoltaic technology landscape [20]. Makrides et al. conducted a research on the effect of temperature on different photovoltaic models [21, 23]. Domitrievska et al. analysed the Raman scattering crystalline evaluation for this technology [24].

\subsection{Wind energy}

Wind energy is the kinetic energy from air motion due to the irregular heating by the Sun to the environment [9]. Electricity can be generated from the harnessing of wind energy by implementing wind turbines that converts the kinetic energy from the wind into electricity $[13,25]$. The average wind speed at Malaysia is around $2 \mathrm{~m} / \mathrm{s}$ which not suitable for wind turbine to generate electricity. However, still some regions of Malaysia at certain time have higher wind speed around $7-15 \mathrm{~m} / \mathrm{s}$. Furthermore, the important

Int J Pow Elec \& Dri Syst Vol. 11, No. 1, Mar 2020 : $433-441$ 
issue of wind energy at Malaysian is the non-uniformity of the wind blow. It means that wind speed varies during the year [26]. Over the years, Malaysia has seen the development in wind turbine technology. According to Akorede et al., the highest energy output by wind energy in Peninsular Malaysia is in Mersing which contributed to $378 \mathrm{MWh}$ of capacity every year [27]. This is then followed by Chuping, which produces $254 \mathrm{MWh}$ annually. Meanwhile, wind electricity in Melaka is accounted to $29 \mathrm{MW}$ h per annum $[27,28]$.

Research has been done to investigate techno-economic, development and feasibility of wind turbine technology in Malaysia [29]. An appraisal by Ho studied on the trend of wind technology in Malaysia based on past, present and future scenario, Goh et al. performed wind energy evaluation by utilizing K-means clustering and Mycielski algorithm for a case study in Kudat, Malaysia [29, 30]. Khalid et al. analysed the economic feasibility of wind resource in Malaysia with numerical weather prediction (NWP) method [31]. Albani et al. conducted optimization of wind energy feed-in tariff (FiT) rates in Malaysia by cost-based approach [32]. Hamdan et al. evaluated a review for Vertical Axis Wind Turbine (VAWT) system in the field of micro energy harvester in Structural Health Monitoring (SHM) for the case of Malaysia [33]. Wong et al. performed a review on VAWT efficiency advancements using flow augmentation method [34]. Suffer et al. and Kadhim et al. modelled and performed numerical simulation for four cavity blades and aerodynamic VAWT respectively [27, 28]. Loon et al. and Aravind et al. conducted analysis on the concept of magnetic levitation on VAWT [35]. Wen et al. investigated performance optimization for small Horizontal Axis Wind Turbine (CS-SHAWT) [17, 29]. Wang et al. studied the impacts of irregular wind on a newly developed cross-axis wind turbine performance [36]. Hussain et al., Razliana et al. and Daut et al. proposed wind power as an alternative power source in Perlis [30,37]. Al-Aqel et al. examined the potential of small wind turbines for highways in Malaysia [32]. Khalid and Nor Musa proposed a newly concept of VAWT farms in a mission to harvest aerodynamic energy losses on highways in Malaysia [32]. Zaharim et al. assessed the effect of wind technology for rural area dwellers in Mersing [33]. Masseran et al. evaluated wind power regional assessment based on several wind speed densities [33]. Islam et al. analysed the wind energy possibility in Kudat and Labuan using Weibull distribution function [29, 31]. Bhayo et al. evaluated wind energy conversion system on static and dynamic features using wind turbine simulator [36]. Rosmin et al. conducted efficiency comparison between three micro-sized blade rotor models based on Malaysian wind speed context $[32,34]$. Chong et al. assessed the design of an energy recovery system for wind turbine generator to conserve energy in commercial buildings [34]. Yap et al. designed the optimization of exhaust air energy recovery for wind turbine generator on shroud-augmented dual-rotor case using hybrid non-destructive assessment technique [33-35].

\subsection{Biomass}

Biomass are the organic wastes of plants and animals, which is a type of renewable energy that can generate electricity through biofuels [36]. Biofuels are the type of biomass in the form of gas and liquid, that can be obtained by applying different sorts of technology [36, 37]. Malaysia has high capability of biomass resources. The important exist resources at Malaysia are agriculture waste such as rice husk and sugarcane bagasse, forest residue and wood waste, animal manure, municipal solid waste, dedicated biomass crops and palm oil biomass. Malaysia is one of the largest palm oil exporters in the world. Therefore, huge amount of the palm oil waste is available at Malaysia. As an example, around 80 million tons of pam oil waste was produced in 2011. The two of main sources of biomass in Malaysia are palm oil waste and sugar cane waste [38].

Several researchers emphasised that biomass energy is preferred as the solution for an eco-friendly resource of electricity generation due to its ability to absorb the amount of carbon dioxide it releases in the production, which is sustainable [36-39]. In addition, biomass is known for its abundancy, local availability and capability to generate low-cost electricity with elevated performance.

According to Jayakumar et al., biomass accounted for a percentage of $4 \%$ of Malaysian total energy consumption alongside with coal, natural gas, hydroelectricity and petroleum by 2012 [40]. Seng et al. described the percentage of biomass wastes utilized for electricity in Malaysia is only 5\%. Sabah utilized biomass from palm oil waste to generate electricity with annual capacity of 3,300 $\mathrm{GWh}$ [41]. However, the remaining $95 \%$ of total biomass waste in the country remained as wastes and not utilized due to the difficulties in transportation cost to transfer the wastes from plantation to power stations.

Research has been done to analyse the biomass electricity and technology in Malaysia. Evaluation on the transportation decision tool regarding biomass supply chain is conducted involving biomass allocation planning, processing station selection and vehicle capacity constraint. Tan et al. designed the spatial and economic aspect for oil palm biomass as energy production in the objective to minimize issues regarding transboundary haze $[42,43]$. Mohd Shaharin et al. suggested on ways to strengthen palm oil biomass industry for the case of Malaysia [43, 44]. Nor Aishah and Amin uses INCAM model to perform assessment on 
carbon dioxide emission reduction in the context of biomass power plants in Malaysia for the year of 2016 [40]. Ng et al., Mohd Shaharin et al., Abnisa et al. and Ooi et al. studied the potentiality of palm biomass in Malaysia [43-45]. Mohd Shaharin et al. and Darshini et al. conducted an industry survey on sustainable electricity production from oil palm biofuel and biomass [46-48]. Mekhilef et al. and Shafie et al. assessed the current prospects of biomass energy [49].

\section{SIZING AND OPTIMIZING OF RENEWABLE ENERGY IN MALAYSIA}

Malaysia is a tropical country rich in resources beneficial in electricity generation as it is located in equatorial region, situated in the range of $1^{\circ}$ and $7^{\circ}$ North and $100^{\circ}$ and $120^{\circ}$ East, therefore having an abundance of solar irradiance of average $1700 \mathrm{~W} / \mathrm{m}^{2}$ annually [3, 32, 33]. Meanwhile, its annual average wind velocity of around 1.2 to $4.1 \mathrm{~m} / \mathrm{s}$, where the highest wind velocity is recorded in the east of Peninsular Malaysia [18]. Malaysian government has taken many initiatives to exploit the substantial available energy sources including announcing to include renewable energy as a fuel for electricity generation complementing gas, oil, coal and hydro in its eighth Malaysia Plan [3]. According to 'World development indicators: Electricity production, sources and access' (2017), the statistics show the generation of electricity in Malaysia from renewable resources accounted to 0.6 percent of the total generation by 2015 . Therefore, the electricity generation from renewable sources in Malaysia is anticipated to grow in the future alongside the government endorsement due to its clean, eco-friendly and free source of energy which can highly reduce the dependency on oil and gas that emits harmful pollutants to the environment.

Henceforth, the optimizing and sizing of hybrid renewable energy by the researchers becomes essential to mitigate the intermittent nature of renewable energy. Many researchers have taken their part in doing the study on the optimization for hybrid renewable energy system in Malaysia. Halabi and Mekhilef in their study optimized the hybrid configurations for a village in Sabah, Malaysia involving diesel generators and PV array for both on-grid and off-grid modes of operation and obtained the most optimal solution consisting of PV arrays of $300 \mathrm{kWp}$, two diesel generators of $50 \mathrm{~kW}$ and $100 \mathrm{~kW}$, a $150 \mathrm{~kW}$ converter and $330 \mathrm{kWh}$ battery banks [34, 35]. Izadyar et al. utilized Homer to find the potential regions for the implementation of hybrid renewable energy system in Malaysia [36]. The results concluded Langkawi and Tioman islands have the most potential for solar and wind hybrid, while Teluk Burau and Durian which located in Langkawi has an attractive opportunity for solar/wind/micro hydropower hybrid. In addition, solar and micro hydropower combination is the most optimal to be implemented in Lawas and Ranau, located in Sarawak and Sabah respectively. Ngan and Tan simulated hybrid optimization in Homer for Johor Bahru with the optimal configuration consisting PV, wind, diesel and battery system as an alternative from the existing stand-alone diesel system [37].

Ismail et al. investigated the techno-economic feasibility evaluation on hybrid system in a typical village in Malaysia. The results indicated the most optimal configuration for the location comprising of a system having PV modules, a diesel generator and a battery bank [38]. Lau et al. performed the feasibility study on stand-alone photovoltaic/diesel generator hybrid system by varying the load sizes, annual real interest rate and diesel price for Malaysian islands [39]. Due to the complexity in fuel transportation for isolated islands in Malaysia, the diesel price can fluctuate and hence, became a concern for the practicality of existing standalone diesel generator system that is currently utilized as the main source of electricity in those islands. The study indicated that the use of photovoltaic/diesel generator/battery hybrid system is feasible at high diesel prices. For the case of Pemanggil Island, Malaysia, Anwari et al. assessed the practicality of hybrid wind and diesel energy with battery systems prospective and acquired that this hybrid scenario is more feasible and economically wise than the existing standalone diesel generator system [40]. The study was particularly based on the variation of diesel costs and wind irradiances. Ashourian et al. appraised the optimal green technology hybrid system in Juara village, situated in Tioman Island, Malaysia by considering the load profile and its geographical condition. The result indicated the most feasible hybrid configuration when the cost of diesel reaches to $\$ 2.10 / \mathrm{L}$ consists of photovoltaic panels and wind turbines having capacities of 200 $\mathrm{kW}$ and $40 \mathrm{~kW}$ respectively combined with a battery storage [41]. Another study on the hybrid system for Tioman Island conducted by Basir Khan et al. resulting in the most optimal system involving PV-hydrodiesel configuration in standalone mode that was simulated in Homer software. This configuration gives the lowest NPC of $\$ 31,901,944$ [42]. Ho et al. evaluated the scenario of biomass and solar town for a smart eco-village, Iskandar Malaysia (IM) and proposed that the most optimal configuration to meet the load demand comprises of $412 \mathrm{~kW}$ biogas thermal power station, a direct-fired biomass of capacity $417 \mathrm{~kW}, 136$ $\mathrm{kW}$ photovoltaic modules and $3046 \mathrm{kWh}$ sodium sulfur battery [43].

Hossain et al. evaluated the optimization for tourist attractions in South China Sea, Malaysia using Homer software and obtained the optimized system resulted consisting of wind, diesel generator, photovoltaic, converter and battery with NPC of \$ 17.15 million and COE of \$ 0.279/kWh [44]. Fadaeenejad

Int J Pow Elec \& Dri Syst Vol. 11, No. 1, Mar 2020 : 433 - 441 
et al. performed a research on the sizing for hybrid system for a village in Malaysia and suggested the most cost-effective configuration is photovoltaic/wind/battery hybrid system [45, 46]. Shezan et al. appraised the techno-economic analysis of hybrid concept to power two residential hotels in Cameron Highlands. The result suggested a hybrid system involving a $4 \mathrm{~kW}$ diesel generator, 15 units of $10 \mathrm{~kW}$ wind turbines and 2 units of battery backup as the most economically and technically feasible to supply the demand [47, 48].

\section{REVIEW OF SOME SUCCESSFUL HYBRID RENEWABLE ENERGY SYSTEMS IN MALAYSIA}

Although the hybrid renewable energy system is not considered new in the research field in Malaysia, there is only quite a number that is implemented in this country as the renewable system applied currently are mostly comprises of standalone system utilizing only a single source of renewable energy, such as standalone photovoltaic system, which is quite popular in the rural parts of the country [50-52]. A few of the application of Hybrid Renewable Energy System (HRES) in Malaysia is reviewed below.

\subsection{Hybrid photovoltaic/diesel standalone system}

The hybrid system is in Pulau Banggi and Tanjung Labian, Sabah. For Pulau Banggi, the photovoltaic provide $69.21 \%$ of the total electricity generation, large generators of capacity $400 \mathrm{~kW}$ produce $37 \%$ and small generators contributed to a proportion of 3.54\%. The renewable fraction of the whole system is $50.4 \%$, with excess energy at $9.3 \%$. Other than that, the hybrid system in Tanjung Labian has $86.90 \%$ of its total energy production from photovoltaic, while large generators of capacity $500 \mathrm{~kW}$ produced $9.42 \%$ and small generators generated $3.68 \%$ of electricity. The renewable fraction of the system is indicated by $80.7 \%$, while the excess energy is at $17.4 \%[50,51]$. In addition, solar hybrid power system which incorporated both solar photovoltaic and diesel generators as the source back up has light up homes in Bario Highlands, Rumah Dau and Long Urun in Sarawak. The hybrid system in Bario Highlands provides $887 \mathrm{~kW}$ capacity of energy, powering up 233 households, shops and offices [52-54]. Besides, Rumah Dau hybrid system provides electricity for 26 households and a school with the energy capacity of $129.6 \mathrm{~kW}$ [55- 57]. Furthermore, 689 $\mathrm{kW}$ solar/diesel generator hybrid system in Long Urun has light up 245 households in 12 villages, namely Long Data Sengelang, Long Ketuet, Long Balau, Long Sivau, Long Apok, Long Liten, Uma Pawa, Rumah Pera, Long Tengah 1, Long Tengah 2, Uma Badeng and Long Dulit [58].

\subsection{Hybrid photovoltaic/wind/diesel standalone system}

The hybrid photovoltaic/wind/diesel standalone system is applied to a fishermen village, located at Perhentian Island, Malaysia. The purpose of the hybrid system is to provide a continuous supply of electricity and reduce the dependency on diesel generators that was previously the main source of electricity in the village. The components of the hybrid system include $100 \mathrm{~kW}$ PV module, 2 units of wind turbines at capacity $100 \mathrm{~kW}, 1$ unit of $100 \mathrm{~kW}$ diesel generator set, 240 Volt DC $480 \mathrm{kWh}$ battery storage, set control system for multiple generator and hybrid control system. It is notable that the total energy production from renewable sources recorded to be $75 \mathrm{~kW}$ as photovoltaic provides $39 \mathrm{~kW}$ of electricity and both wind turbine produces $18 \mathrm{~kW}$ individually [56].

\subsection{Hybrid photovoltaic/wind standalone system}

The photovoltaic/wind HRES is implemented at Samunsan Forest and Wildlife Sanctuary, which is $60 \mathrm{~km}$ north of Kuching, Sarawak. The purpose of the hybrid system is to provide an eco-friendly and reliable electricity for the community living in the area, scientists and tourists. The system component incorporated $900 \mathrm{~W}$ PV module, $2.5 \mathrm{~kW}$ wind turbines launched on a $26 \mathrm{~m}$ tower, $30 \mathrm{~kW}$ diesel generator, 2 units of $2 \mathrm{kWh}$ lead acid batteries, $5 \mathrm{~kW}$ inverter and remote monitoring set. The generation of electricity by wind turbines are the most throughout the year. When the wind velocity is low especially in the summer, PV provides its maximum output complemented by diesel generators to supply the increasing demand from research, community and tourism activities [21, 59].

Table 1 shows the renewable energy target at Malaysia from 2015 to 2050. Based on this table Malaysia will improve and increase their capability to generate electricity by solar energy in future $[49,57]$. Based on the review, some of the reasons and challenges that affect popularity of renewable energy in Malaysia are listed in Table 2. 
Table 1. Renewable energy generation target in Malaysia 2015-2050 (MW) [53]

\begin{tabular}{lllllll}
\hline Year & Biomass & Biogas & Mini-Hydro & Solar PV & Solid Waste & Total \\
\hline 2015 & 330 & 100 & 290 & 65 & 200 & 985 \\
\hline 2020 & 800 & 240 & 490 & 190 & 360 & 2,080 \\
\hline 2025 & 1,190 & 350 & 490 & 455 & 380 & 2,865 \\
\hline 2030 & 1,340 & 410 & 490 & 1,370 & 390 & 4,000 \\
\hline 2050 & 1,340 & 410 & 490 & 18,700 & 430 & 21,370 \\
\hline
\end{tabular}

Table 2. Challenges that affect popularity of renewable energy in Malaysia

\begin{tabular}{|c|c|c|c|c|c|}
\hline Type of & \multicolumn{5}{|c|}{ Challenges that affect popularity of renewable energy in Malaysia } \\
\hline $\begin{array}{l}\text { Solar } \\
\text { energy }\end{array}$ & Cost & $\begin{array}{l}\text { Average of } 2 \text { months } \\
\text { cloudy or raining day per } \\
\text { year }\end{array}$ & $\begin{array}{l}\text { High ambient } \\
\text { temperature (inefficiency } \\
\text { of solar panels) }\end{array}$ & $\begin{array}{l}\text { land required for } \\
\text { harvesting solar energy }\end{array}$ & $\begin{array}{l}\text { Battery short lifespan } \\
\text { due to overused without } \\
\text { recharging }\end{array}$ \\
\hline $\begin{array}{l}\text { Wind } \\
\text { energy }\end{array}$ & $\begin{array}{l}\text { Low average } \\
\text { wind speed }\end{array}$ & Noise pollution & $\begin{array}{l}\text { Disturbance and } \\
\text { destruction of ecosystems }\end{array}$ & $\begin{array}{l}\text { Affect fauna, especially } \\
\text { birds }\end{array}$ & $\begin{array}{l}\text { Waste of space (land) for } \\
\text { turbine installation }\end{array}$ \\
\hline Biomass & $\begin{array}{l}\text { Difficult to } \\
\text { transport }\end{array}$ & $\begin{array}{l}\text { Complexity in } \\
\text { harvesting, collecting } \\
\text { and processing }\end{array}$ & $\begin{array}{l}\text { Low efficiency of } \\
\text { equipment to produce } \\
\text { energy }\end{array}$ & $\begin{array}{l}\text { Low number of market } \\
\text { players for biomass } \\
\text { energy business }\end{array}$ & $\begin{array}{l}\text { Requires financial } \\
\text { assistance and } \\
\text { technological support }\end{array}$ \\
\hline Hybrid & Cost & $\begin{array}{l}\text { Complexity in finding } \\
\text { the best combination of } \\
\text { hybrid system }\end{array}$ & $\begin{array}{l}\text { Highly dependent on } \\
\text { meteorological condition }\end{array}$ & $\begin{array}{l}\text { Highly dependent on } \\
\text { availability of energy } \\
\text { sources }\end{array}$ & $\begin{array}{l}\text { Lack of trained } \\
\text { personnel }\end{array}$ \\
\hline
\end{tabular}

\section{CONCLUSION}

This paper conducted a review on the available renewable energy system in Malaysia. Based on the review various research has been conducted by researchers to analyse the performance of renewable energy system such as solar, wind, biomass and hybrid renewable energy in Malaysia. Malaysia government had aimed to generate $5.5 \%$ of total electricity from renewable energy by 2015 . However, the new target for Malaysia is $20 \%$ by 2030 . Based on the review some of the renewable energy such as wind energy might be not feasible for Malaysia. But, still it can be the suitable alternative for certain region where we have high wind speed at some period time of the year such as Perhentian Island. According to the review, just $5 \%$ of the biomass wastes utilized for electricity in Malaysia. It means that the huge amount of the capability of biomass energy is wasting and Malaysia can concentrate to generate electricity from existing biomass. Baes on the review, Hybrid renewable energy system is not yet popular in Malaysia due to cost and low wind speed. Therefore, there is only quite a number that is implemented in this country as the renewable system applied currently are mostly comprises of standalone system utilizing a single source of renewable energy such as standalone photovoltaic system, which is quite popular in the rural parts of the country.

\section{REFERENCES}

[1] PGV. Sampaio, MOA. Gonzalez, "Photovoltaic solar energy: Conceptual framework," Renewable and Sustainable Energy Reviews Elsevier, vol. 74, pp. 590-601, 2017.

[2] H. N. Afrouzi, S. V. Mashak, Z. Abdul-Malek, K. Mehranzamir, B. Salimi., "Solar array and battery sizing for a photovoltaic building in Malaysia," Jurnal Teknologi, vol. 64, No. 4, 2014.

[3] M. Almaktar, H. Abdul Rahman, M. Yusri Hassan, W.Z. Omar., "Photovoltaic technology in Malaysia: past, present, and future plan," International Journal of Sustainable Energy, vol. 34, no. 2, pp. 128-140, 2013.

[4] M. Hernandez, J. Alonso, J. Hernandez-Alvarez., "An overview of solar photovoltaic energy in Mexico and Germany," Renewable and Sustainable Energy Reviews Elsevier, vol. 31, pp. 639-649, 2014.

[5] S. Mekhilefa, A. Safari, W. E. Mustaffaa, R. Saidurb, R. Omara, M. A. Younis., "Solar energy in Malaysia: Current state and prospects," Renewable and Sustainable Energy Reviews, vol. 16, pp. 386-396, 2012.

[6] H. N. Afrouzi, S. H. W. Yii, J. Ahmed, M. Tabassum., "Comprehensive Review on Appropriate Sizing and Optimization Technique of Hybrid PV-Wind system," IEEE PES Asia-Pacific Power and Energy Engineering Conference (APPEEC), vol. 47, pp. 364-369, 2018.

[7] B. Bakhtyar, O. Saadatian, MA. Alghoul, Y. Ibrahim, K. Sopian, "Solar electricity market in Malaysia: A review of feed-in tariff policy," Wiley Online Library, vol. 34, no. 2, pp. 600-606, 2014.

[8] H. Pan, L. Qi, X. Zhang, W. Salman, Y. Yuan., "A portable renewable solar energy-powered cooling system based on wireless power transfer for a vehicle cabin." Solar Energy- Elsevier, vol. 195, pp. 334-343, 2017.

[9] V. Khare, S. Nema, P. Baredar., "Solar-wind hybrid renewable energy system: A review," Sustainable Energy Reviews, Elsevier, vol. 58, pp. 23-33, 2016.

[10] J. Wong, YS. Lim, JH. Tang, E. Morris., "Grid-connected photovoltaic system in Malaysia: A review on voltage issues," Renewable and Sustainable Energy Reviews, Elsevier, vol. 29, pp. 535-545, 2014.

Int J Pow Elec \& Dri Syst Vol. 11, No. 1, Mar 2020 : 433 - 441 
[11] MM. Rahman, M. Hasanuzzaman, NA. Rahim, "Effects of operational conditions on the energy efficiency of photovoltaic modules operating in Malaysia," Sustainable Energy Reviews, Elsevier, vol. 143, pp. 912-924, 2017.

[12] GVD. Kaa, J. Rezaei, L. Kamp, AD. Winter, "Photovoltaic technology selection: A fuzzy MCDM approach," Renewable and Sustainable Energy Reviews, Elsevier, vol. 32, pp. 662-670, 2014.

[13] M. S. Ismail, M. Moghayyemi, TMI. Mahlia, "Techno-economic analysis of an optimized photovoltaic and diesel generator hybrid power system for remote houses in a tropical climate," Sustainable Energy Reviews, Elsevier, vol. 69, pp. 163-173, 2013.

[14] KY. Lau, C.W. Tan, A.H. Yatim, "Photovoltaic systems for Malaysian islands: Effects of interest rates, diesel prices and load sizes," Sustainable Energy Reviews, Elsevier, vol. 83, pp. 204-216, 2015.

[15] H. N. Afrouzi, S. V. Mashak, K. Mehranzamir, B. Salimi., "Sizing of required photovoltaic array for a building in Malaysia with matlab," IEEE Third International Conference on Computational Intelligence, Modelling \& Simulation, vol. 86, pp. 86-91, 2011.

[16] PGV. Sampaio, MOA. Gonzalez, RMD. Vasconcelos, MATD. Santos, JCD. Toledo, JPP. Pereira, "Photovoltaic technologies: Mapping from patent analysis," Renewable and Sustainable Energy Reviews, Elsevier, vol. 93, pp. 215-224, 2018.

[17] BA. Wender, RW. Foley, V. Prado-Lopez, D. Ravikumar, DA. Eisenberg, TA. Hottle, J. Sadowski, WP. Flanagan, A. Fisher, L. Laurin, ME. Bates, I. Linkov, TP. Seager, MP. Fraser, DH. Guston, "Illustrating anticipatory life cycle assessment for emerging photovoltaic technologies," Pubmed, Elsevier, vol. 48, no. 18, pp. 10531-10538, 2014.

[18] S. Giraldo, Z. Jehl, M. Placidi, V. Izquierdo-Roca, A. Perez-Rodriguez, E. Saucedo., "Progress and perspectives of thin film Kesterite photovoltaic technology: A critical review," PubMed, Elsevier, 2019.

[19] Zhou, Z, M. Carbajales-Dale., "Assessing the photovoltaic technologu landscape: Efficiency and energy return on investment (EROI)," Energy \& Environmental Science, vol. 11, no. 3, pp. 603-608, 2018.

[20] G. Makrides, B. Zinsser, A. Phinikarides, M. Schubert, GE. Georghiou, "Temperature and thermal annealing effects on different photovoltaic technologies," Renewable Energy, Elsevier, vol. 43, pp. 407-417, 2012.

[21] H.N. Afrouzi, S.V. Mashak, A.M Dastgheib, J. Tavalaei., "Economic Sizing of Solar Array for a Photovoltaic Building in Malaysia with Matlab," IEEE First International Conference on Informatics and Computational Intelligence, vol. 65, pp.170-175, 2011.

[22] A. A. F. Husain, W. Z. W. Hasan, S. Shafie, M. N. Hamidon, S. S. Pandey., "A review of transparent solar photovoltaic technologies," Renewable and Sustainable Energy Reviews, Elsevier, vol. 94, pp. 779-791, 2018.

[23] H.N. Afrouzi., "Sizing and economic evaluation of building integrated photovoltaic in Malaysia," M.S. thesis, Universiti Teknologi Malaysia, 2010.

[24] P. Ooshaksaraei, B. Ali, S. Mat, M. Yahya, K. Ibrahim, A. Zaharim, K. Sopian., "Large scale solar hot water heating systems for green hospital," Latest Trends in Renewable Energy and Environmental Informatics, pp. 161-165, 2019.

[25] M. Rahman, ZC. Ong, WT. Chong, S. Julai, SY. Khoo, "Performance enhancement of wind turbine systems with vibration control: A review," Sustainable Energy Reviews, Elsevier, vol. 51, pp. 43-54, 2015.

[26] C.T. Sung., "Possibility of electricity from wind energy in Malaysia: Some rough calculations," Getting wind of the situation, Green Technology section, pp. 7, 2013.

[27] M. F. Akorede, I. Muhd, H. Mohd, S. Norainon., "Appraising the viability of wind energy conversion system in the Peninsular Malaysia," Sustainable Energy Reviews, Elsevier, vol. 76, pp. 801-810, 2013.

[28] H. S. Kadhim, G. A. Quadir, A. K. Farhan, U. Ryspek, K. A. Ismail., "Numerical simulation for the aerodynamic vertical axis wind turbine with two different rotors having movable vanes," Applied Mechanics and Materials, ProQuest Central, vol. 786, pp. 205-209, 2015.

[29] H. H. Goh, K. C. Goh, S. W. Lee, Q. S. Chua, K. Teo., "Wind energy assessment considering wind speed correlation in Malaysia," Sustainable Energy Reviews, Elsevier, vol. 54, pp. 1389-1400, 2016.

[30] L. Ho., "Wind energy in Malaysia: Past, present and future," Sustainable Energy Reviews, Elsevier, vol. 53, pp. 279-295, 2016.

[31] M. Khalid, H. Shaaban., "Feasibility assessment of wind energy resources in Malaysia based on NWP models," Sustainable Energy Reviews, Elsevier, vol. 62, pp. 147-154, 2014.

[32] A. Albani, Z. Mohd, I. Che Mohd., "The optimal generation cost-based tariff rates for onshore wind energy in Malaysia," EBSCOhost, vol. 10(8), pp. 1114-1126, 2017.

[33] W. C. Wang, J. J. Wang, W. T. Chong., "The effects of unsteady wind on the performances of a newly developed cross-axis wind turbine: A wind tunnel study," Renewable Energy, Elsevier, vol. 131, pp. 644-659, 2019.

[34] K. H. Wong, W. T. Chong, S. Nazatul Liana, S. C. Poh, Y. Shiah, C. Wang., "Performance enhancements on vertical axis wind turbines using flow augmentation systems: A review," Renewable and Sustainable Energy Reviews, Elsevier, vol. 73, pp. 904-921, 2017.

[35] K. H. Suffer, R. Usubamatov, G. A. Quadir, K. A. Ismail., "Modeling and numerical simulation for the newly designed four cavity blades vertical axis wind turbine," Applied Mechanics and Materials, ProQuest Central, vol. 554, pp. 536-540, 2014.

[36] H. Long, X. Li,H. Wang, J. Jia., "Biomass resources and their bioenergy potential estimation: A review," Sustainable Energy Reviews , Elsevier, vol. 26, pp. 344-352, 2013.

[37] V. K. Sharma, K. Ullah, S. Dhingra, G. Braccio, M. Ahmad, S. Sofia., "Assessing the lignocellulosic biomass resources potential in developing countries: A critical review," Sustainable Energy Reviews, Elsevier, vol. 51, pp. 682-698, 2015.

[38] P. K. Halder, N. Paul, MRA. Beg, "Assessment of biomass energy resources and related technologies practice in Bangladesh," Sustainable Energy Reviews, Elsevier, vol. 39, pp. 444-460, 2014. 
[39] GMJ. Herbert, AU. Krishnan, "Quantifying environmental performance of biomass energy," Sustainable Energy Reviews, Elsevier, vol. 59, pp. 292-308, 2016.

[40] S. Jayakumar, M. Hasbi, GP. Maniam, N. Govindan., "The prospect of microalgal biodiesel using agro-industrial and industrial wastes in Malaysia," Sustainable Energy Reviews, Elsevier, vol. 72, pp. 33-47, 2017.

[41] L. Y. Seng, K. S. Lee, S. Morris., "Methodology for optimizing geographical distribution and capacities of biomass power plants in Sabah, East Malaysia," Emerald Resources, vol. 8(1), pp. 100-120, 2017.

[42] S. T. Tan, A. Haslenda, J. S. Lim, A. Bakar., "Economic and spatial planning for sustainable oil palm biomass resources to mitigate transboundary haze issue," Sustainable Energy Reviews, Elsevier, vol. 146, pp. 169-178, 2018.

[43] U. Mohd Shaharin, P. Jennings, T. Urmee., "Generating renewable energy from oil palm biomass in Malaysia: The Feed-in Tariff policy framework," Biomass and Bioenergy, Elsevier, vol. 62, pp. 37-46, 2014.

[44] M. Shaharin, P. Jennings, T. Urmee, "Strengthening the palm oil biomass renewable energy industry in Malaysia," Sustainable Energy Reviews, Elsevier, vol. 60, pp. 107-115, 2013.

[45] J. Ben-Iwo, V. Manovic, P. Longhurst., "Biomass resources and biofuels potential for the production of transportation fuels in Nigeria," Sustainable Energy Reviews, Elsevier, vol. 63, pp. 172-192, 2016.

[46] P. Thomas, N. Soren, NP. Rumjit, J G. James, MP. Saravanakumar, "Biomass resources and potential of anaerobic digestion in Indian scenario," Sustainable Energy Reviews, Elsevier, vol. 77, pp. 718-730, 2017.

[47] Y. Li, L. W. Zhou, R. Z. Wang, "Urban biomass and methods of estimating municipal biomass resources," Sustainable Energy Reviews, Elsevier, vol. 80, pp. 1017-1030, 2017.

[48] Z. X. Ooi, Y. P. Teoh, B. Kunasundari, S. H. Shuit., "Oil palm frond as a sustainable and promising biomass source in Malaysia: A review," Environmental Progress \& Sustainable Energy, Wiley Online Library, vol. 36, no. 6, pp. 1864-1874, 2017.

[49] L. M. Halabi, L. M, S. Mekhilef., "Flexible hybrid renewable energy system design for a typical remote village located in tropical climate," Sustainable Energy Reviews, Elsevier, vol. 177, pp. 908-924, 2018.

[50] L. M. Halabi, L. M, S. Mekhilef, L. Olatomiwa, J. Hazelton., "Performance analysis of hybrid PV/diesel/battery system using HOMER: A case study Sabah, Malaysia," Elsevier, vol. 144, pp. 322-339, 2017.

[51] N. Izadyar, H. C. Ong, W. T. Chong, J. C. Mojumder, K. Y. Leong, "Investigation of potential hybrid renewable energy at various rural areas in Malaysia," Sustainable Energy Reviews, Elsevier, vol. 139, pp. 61-73, 2016.

[52] M. S. Ngan, C. W. Tan., "Assessment of economic viability for PV/wind/diesel hybrid energy system in southern peninsular Malaysia", Sustainable Energy Reviews , Elsevier, vol. 16, no. 1, pp. 634-647, 2012.

[53] M. H. Ashourian, S. M. Cherati, A. A Mohd Zin, M. Anwari., "Optimal green energy management for island resorts in Malaysia," Sustainable Energy Reviews, Elsevier, vol. 51, pp. 36-45, 2013.

[54] M. R. Basir Khan, R. Jidin, J. Pasupuleti, S. A. Shaaya., "Optimal combination of solar, wind, micro-hydro and diesel systems based on actual seasonal load profiles for a resort island in the South China Sea," Sustainable Energy Reviews , Elsevier, vol. 82, pp. 80-97, 2015.

[55] W. S. Ho, H. Hashim, J. S. Lim., "Integrated biomass and solar town concept for a smart eco-village in Iskandar Malaysia (IM)," Sustainable Energy Reviews, Elsevier, vol. 69, pp. 190-201, 2014.

[56] M. Hossain, S. Mekhilef, O. Lanre., "Performance evaluation of a stand-alone PV-wind-diesel-battery hybrid system feasible for a large resort center in South China Sea, Malaysia," Sustainable Energy Reviews, Elsevier, vol. 28, pp. 358-366, 2017.

[57] M. Fadaeenejad, M. A. Radzi, M. Z. Kadir, H. Hizam., "Assessment of hybrid renewable power sources for rural electrification in Malaysia," Sustainable Energy Reviews, vol. 30, pp. 299-305, 2014.

[58] S. K. A. Shezan, R. Saidur, K. R. Ullah, A. Hossain, W. T. Chong, S. Julai, S., "Feasibility analysis of a hybrid offgrid wind-DG-battery energy system for the eco-tourism remote areas," Sustainable Energy Reviews, vol. 17 , no. 8, pp. 2417-2430, 2015.

[59] Z. Darus, N. A. Hashim, S. N. Abdul Manan, M. A. Abdul Rahman, K. N. Abdul Maulud, O. Karim., "The development of hybrid integrated renewable energy system (wind and solar) for sustainable living at Perhentian Island, Malaysia," European Journal of Social Sciences, vol. 9(4), pp. 557-563, 2009.

Int J Pow Elec \& Dri Syst Vol. 11, No. 1, Mar 2020 : $433-441$ 


\section{BIOGRAPHIES OF AUTHORS}
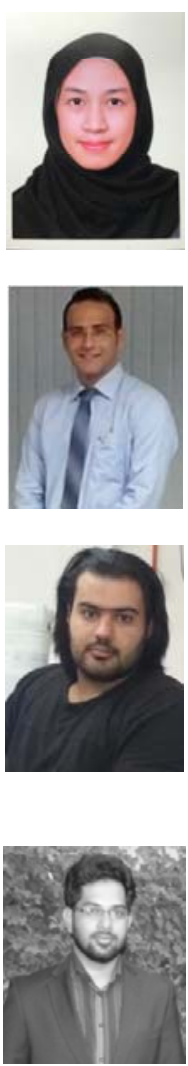

Nur Huda Munirah binti Tambi is currently doing her Final Year in Bachelor of Engineering (Electrical and Electronic) (Honours) at Swinburne University of Technology Sarawak. She is always curious and interested in electrical engineering field especially in renewable energy. Being a Sarawakian, she understands the importance and needs for rural electrification in Sarawak and interested to pursue her career in this field.

Hadi Nabipour-Afrouzi received his doctorate in Electrical Engineering in 2015 from Universiti Teknologi Malaysia (UTM). Currently he is working as a lecturer in Swinburne University of Technology Sarawak, Malaysia. His research interests are high voltage engineering, partial discharge phenomenon, fault in high voltage insulators, renewable energy.

Kamyar Mehranzamir received his doctorate in Electrical Engineering in 2015 and he is an assistant professor in the department of Electrical and Electronic Engineering at University of Nottingham Malaysia. His research interests include high voltage and high current engineering and renewable energy industry.

Jubaer Ahmed (M'2016) received the B.Sc. degree in Electrical and Electronics Engineering from Bangladesh University of Engineering and Technology (BUET) (2012) and Ph.D. from Universiti Teknologi Malaysia (UTM) (2016). Currently he is working as a lecturer in Swinburne University of Technology Sarawak, Malaysia. His research interests include photovoltaic modeling and control, energy conversion from renewable sources and power electronics. 